\title{
Renal Vein Leiomyosarcoma
}

National Cancer Institute

\section{Source}

National Cancer Institute. Renal Vein Leiomyosarcoma. NCI Thesaurus. Code C5388.

An aggressive malignant smooth muscle neoplasm, arising from the renal vein. It is characterized by a proliferation of neoplastic spindle cells. 